\title{
The ecological and economic values of a 50 years old secondary forest in East Kalimantan, Indonesia
}

\author{
KARMINI $^{1, \boldsymbol{v}}$, KARYATI $^{2, v v}$, KUSNO YULI WIDIATI $^{2}$ \\ ${ }^{1}$ Faculty of Agriculture, Universitas Mulawarman. Jl. Pasir Balengkong, Kampus Gunung Kelua, Samarinda 75123, East Kalimantan, Indonesia \\ Tel.: +62-541-749161, Fax.: +62-541-738341, ^email: karmini@ faperta.unmul.ac.id \\ ${ }^{2}$ Faculty of Forestry, Universitas Mulawarman. Jl. Penajam, Kampus Gunung Kelua, Samarinda 75123, East Kalimantan, Indonesia \\ Tel.: +62-541-735089, 749068, Fax.: +62-541-735379, ^^email: karyati@ fahutan.unmul.ac.id
}

Manuscript received: 6 September 2021. Revision accepted: 28 September 2021

\begin{abstract}
Karmini, Karyati, Widiati KY. 2021. The ecological and economic values of a 50 years old secondary forest in East Kalimantan, Indonesia. Biodiversitas 22: 4597-4607. Secondary forests in the tropics are often ignored since they are assumed to have low ecological functions while on the other hand the economic values have been reduced. This study aimed to analyze the ecological and economic values of a 50-year secondary forest in East Kalimantan that experienced several various land-use changes. The ecological aspects analyzed were stand structure, floristic composition, and species diversity. Economic aspects include log prices, logging costs, profit margins, and stumpage values. A vegetation survey of woody trees with a diameter at breast height of more than 5 $\mathrm{cm}$ was carried out on ten plots measuring $20 \mathrm{~m} \times 20 \mathrm{~m}$ each. A total of 437 trees belonging to 38 species, 30 genera, and 19 families were recorded with Moraceae and Euphorbiaceae were the most dominant families with Family Important Value (FIV) of 86.79. The three most dominant species were Macaranga motleyana (IVi of 50.95), Artocarpus elasticus (IVi of 34.41), and Symplocos fasciculata (IVi of 31.46). The trees in the study plot have a diversity index of 1.33 , dominance index of 0.07 , evenness index of 0.37 , and species richness of 6.09. The average logging cost, logs price, lumber price, profit margin, and stumpage value at secondary forest were USD69.43 m $\mathrm{m}^{-3}$, USD44.63 $\mathrm{m}^{-3}$, USD100.03 $\mathrm{m}^{-3}$, USD10.30 $\mathrm{m}^{-3}$, and USD28.73 ha ${ }^{-1}$, respectively. The 50 years old secondary forests in East Kalimantan have biodiversity, especially trees that have economic value, therefore their existence needs to be preserved and their use is carried out by maintaining and increasing biodiversity.
\end{abstract}

Keywords: Abandoned land, diversity, fallow land, secondary forest, stumpage value

\section{INTRODUCTION}

Tropical forest management at a local level requires site-specific information about the region (Manyanda et al. 2021). It is needed information about the transformation process that occurs in the region. This information is important because according to Borges et al. (2021), historical variation of land use will affect the differences in biodiversity and biomass in urban forests and rural forests in the tropics. Furthermore, Naime et al. (2020) explained during the natural regeneration process in tropical secondary forests, there is a change in the magnitude of the trade-off and provision of ecosystem services. Other information that needed to be known relates to biophysical and social-economic variables. Biophysical and social variables are the basis for consideration in understanding the structure and biodiversity of tropical secondary forests (McClellan et al. 2018).

The result of Chen et al. (2020) study showed although tree size and regeneration in the secondary forest are smaller than in the primary forest, woody plant species, species richness, and proportion of young bamboo are generally higher (Chen et al. 2020). Secondary forest is undergoing succession to form tree canopy and palm species composition through the successful growth of seedlings, saplings, and young trees from mature forest species (Norden et al. 2009). Tree diversity of abandoned land increased after 20 years, but remained $22 \%$ lower than natural forest (Nath et al. 2021). In another study, sixty percent of the total basal area and volume were contributed by fast-growing species dominant in secondary forests. In this secondary forest, trees aged 5,10 , and 20 years were categorized as an intermediate diversity, low dominance, and high evenness (Karyati et al. 2018).

Light competition and species characteristics greatly affect tree growth and survival which determine to stand architecture (Khamyong et al. 2018). The surrounding environment affects the plant community at the edge of the forest which typically has a low basal area, tree density, large-diameter trees, and AGB. The distribution of tree species is uniform, but not evenly distributed (Jana and Jusoh 2021). The valuation of tropical forests potential could be done with integration between some indicators of ecosystem services (such as provision, regulating, supporting, and cultural services) and the concept of total economic value (such as use-value, indirect use-value, and no-use value) (Matthew et al. 2019). A study found that the total economic value of forest ecosystem services is estimated at RM 13 billion (Nitanan et al. 2020). While the average value of stump on abandoned land after shifting cultivation and after traditional plantations are USD 83.05 $\mathrm{ha}^{-1}$ and USD $51.56 \mathrm{ha}^{-1}$ respectively (Karmini et al. 2020a, Karmini et al. 2020b).

Many studies report the ecological aspects (Karyati et 
al. 2013, 2018; Chen et al. 2020; Matsuo et al. 2021) and the economic aspects (Naime et al. 2020; Nitanan et al. 2020) of secondary forests separately. Several studies that simultaneously combine the ecological and economic aspects of several secondary forest types with different land-use histories have been reported (Matthew et al. 2019; Karmini et al. 2020a, 2020b). However, similar studies in 50-year-old secondary forest with several different land-use histories are rarely reported. The purpose of this study was to analyze the ecological and economic aspects of a 50year secondary forest in East Kalimantan that experienced several various land-use changes.

\section{MATERIALS AND METHODS}

\section{Study site}

The study was conducted at a secondary forest aged 50 years old in Air Putih area, Samarinda Ulu Sub-district, Samarinda City, East Kalimantan Province, Indonesia. The research plot is located on the side of the Samarinda road to Kutai Kartanegara District at the coordinate point $117^{\circ} 6^{\prime} 29,7641$ "E; 0²6'56,5901"S (Figure 1 and 2). Based on interviews with the landowners, the history of land use of the studied site was forest clearing for shifting cultivation in 1969 . The shifting cultivation activity was stopped due to a forest fire in 1983 which burned all the vegetation in the research plot. The next land use is the cultivation of rubber and local fruits. The land was then left until the research took place, although it was known that there was considerable coal potential in the location.

\section{Procedures}

The study was carried out from March to July 2021. Vegetation survey was conducted at ten plots, each measuring $20 \mathrm{~m} \times 20 \mathrm{~m}$. The measurements of diameter at breast height $(\mathrm{DBH})$ and total tree height, and identification of tree species were performed to all woody trees with $\mathrm{DBH} \geq 5 \mathrm{~cm}$ in the study plot.

\section{Data analysis}

\section{Ecological analysis}

The individual basal area (BA) and volume (V) were measured by using the following formula (Husch et al. 1982):

Individuals $\mathrm{BA}=\pi(\mathrm{DBH} / 2)^{2} \cdot 10^{-4}$

Individuals $\mathrm{V}=1 / 4 \pi \times \mathrm{DBH}^{2} \cdot 10^{-4} \times \mathrm{H} \times f$
Where: DBH is the diameter at breast height $(\mathrm{cm})$, ' $\mathrm{H}$ ' is tree height $(\mathrm{m})$, and ' $f$ ' is form factor.
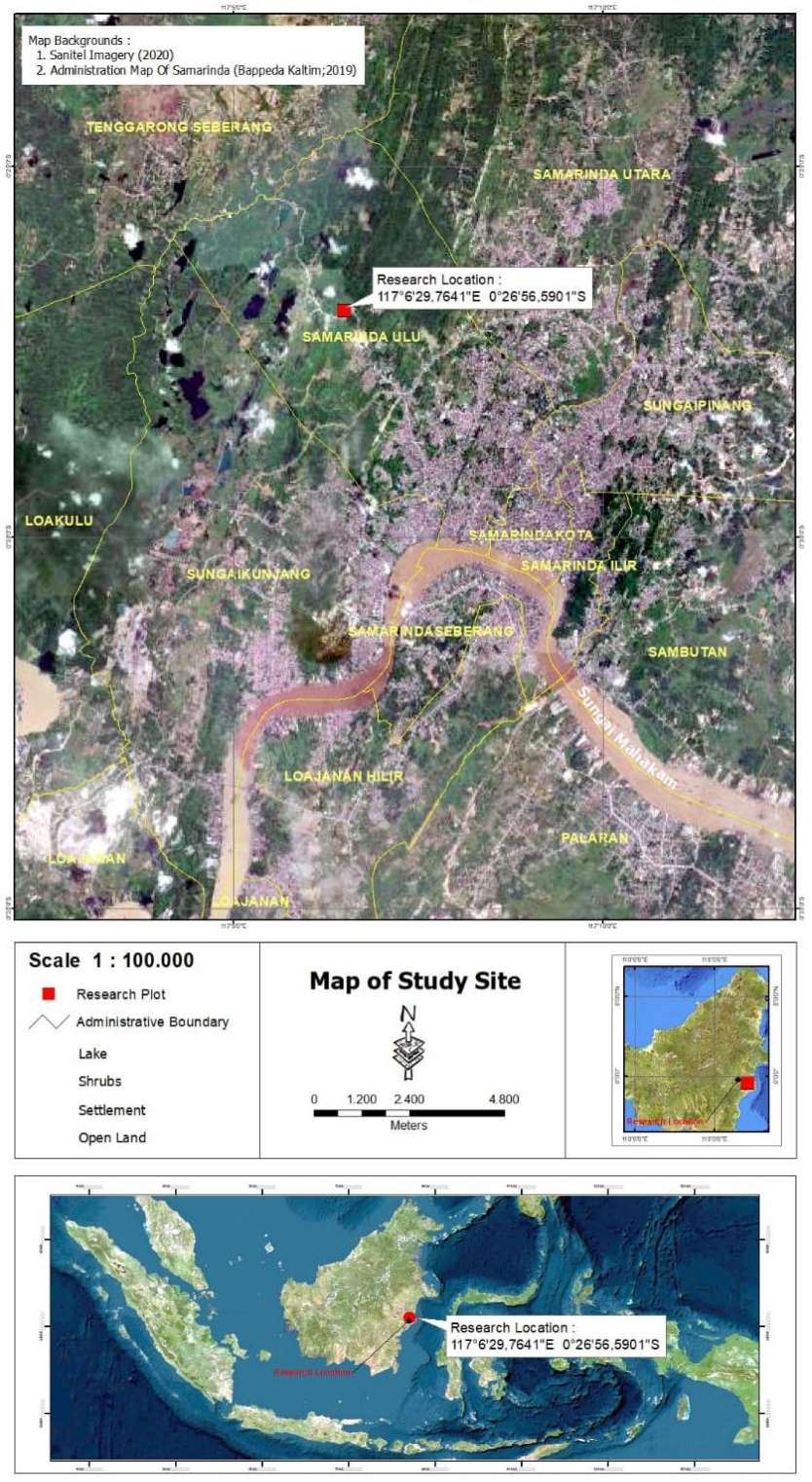

Figure 1. Map of study site in Air Putih area, Samarinda Ulu Subdistrict, Samarinda City, East Kalimantan Province, Indonesia
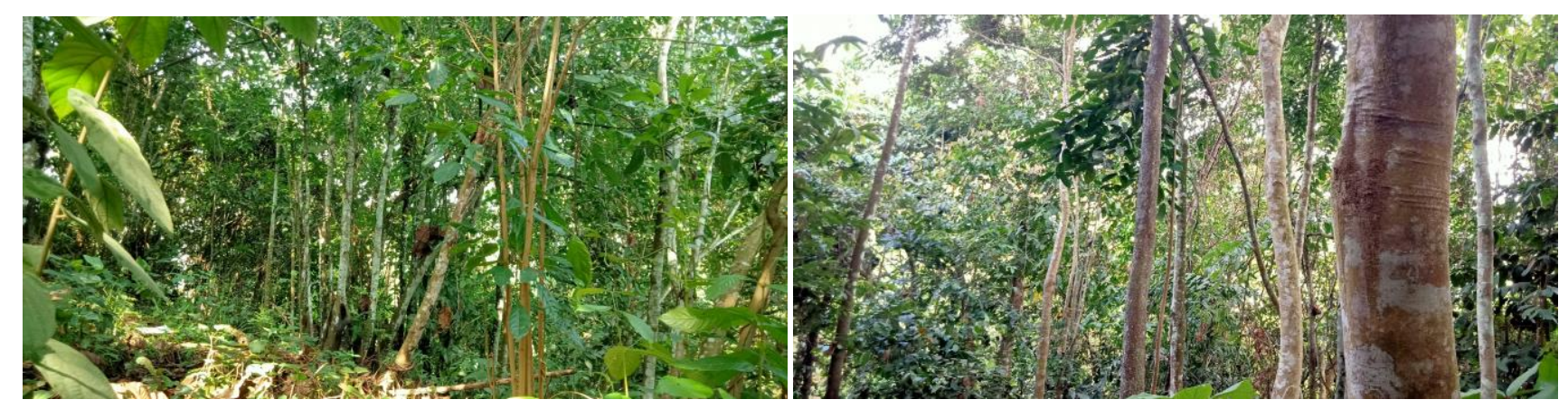

Figure 2. Vegetation condition of a 50 years old secondary forest in East Kalimantan, Indonesia 
The importance value index (IVi) was analyzed to determine the dominant species of community within the studied plots (Fachrul 2007):

$\mathrm{RF}=($ Frequency of a species/Total of frequencies of all species) $\times 100$

$\mathrm{Rd}=$ (The number of individuals of a species/Total number of individuals $) \times 100$

$\mathrm{RD}=($ Total basal area for a species/Total basal area for all species) $\times 100$

$\mathrm{IVi}=\mathrm{RF}+\mathrm{Rd}+\mathrm{RD}$

Where: $\mathrm{RF}$ is relative frequency, $\mathrm{Rd}$ is relative density, and $\mathrm{RD}$ is relative dominance.

The four diversity indices were used to describe the species diversity of standing trees in the studied plots. These diversity indices were Shannon-Wiener's diversity index $\left(H^{\prime}\right)$, Simpson's dominance index $\left(D_{s}\right)$, Pielou's evenness index $\left(J^{\prime}\right)$, and Margalef's richness index $(R)$ (Odum 2005):

$$
\begin{aligned}
& H^{\prime}=-\sum_{i=1}^{s}\left(\frac{n_{i}}{N}\right) \ln \left(\frac{n_{i}}{N}\right) \\
& D_{s}=\sum_{i=1}^{s}\left(\frac{n_{i}}{N}\right)^{2} \\
& J^{\prime}=\frac{H^{\prime}}{\ln (S)} \\
& R=\frac{(S-1)}{\ln n}
\end{aligned}
$$

Where: $\mathrm{n}_{\mathrm{i}}$ : number of individuals of the $i$ - th species, $\mathrm{N}$ : total number of all the individuals in a unit area, and $\mathrm{S}$ : number of species in each plot.

\section{Economic analysis}

The estimation of the price of $\log$ s was carried out in several stages. The tree diameter data that has been collected will be analyzed and continued with the calculation of the number of logs produced from the felled trees. The cost of felling trees was USD69.43 $\mathrm{m}^{-3}$ at the study location at the time of the research. The data in Table 1 shows the number of logs that can be obtained from trees with a diameter of up to $75 \mathrm{~cm}$ and above. Based on the diameter class and the number of $\log$ s, it can be seen the equivalent merchantable height.

The reduction factor in the price of logs was determined based on the Diameter at Breast Height (DBH) size class and the data can be seen in Table 2. The high number of trees with DBH size class $<15 \mathrm{~cm}$ on study location was the background of Karmini et al. (2020b) determine the assumption that the price reduction factor for $\log$ s with a DBH size class $<15 \mathrm{~cm}$ is 0.60

This study also set a profit ratio of $30 \%$ and profit margin was determined by the formula according to Dahalan (2011) as follows:

$$
P M_{i j}=\sum_{i=1}^{n} \sum_{j=1}^{k}\left(P_{i j} x P R\right) /(1+P R)
$$

Table 1. Merchantable tree heights in the studied site of secondary forest

\begin{tabular}{lcc}
\hline $\begin{array}{l}\text { Diameter } \\
\text { class } \mathbf{( c m})\end{array}$ & $\begin{array}{c}\text { Number of logs } \\
\mathbf{5} \text { m long) }\end{array}$ & $\begin{array}{c}\text { Equivalent } \\
\text { merchantable height }(\mathbf{m})\end{array}$ \\
\hline$<15$ & 0.5 & $2.5^{*}$ \\
$15-30$ & 1 & 5 \\
$+30-60$ & 2 & 10 \\
$+60-75$ & 3 & 15 \\
75 up & 4 & 20 \\
\hline Note: Forestry Department of Peninsular Malaysia (FDPM) (1997) as \\
cited by Dahalan (2011); Karmini et al. (2020a); *Karmini et al. \\
(2020b)
\end{tabular}

Table 2. Reduction factor of logs price based on DBH class

\begin{tabular}{lc}
\hline DBH size class $(\mathbf{c m})$ & Reduction factor \\
\hline$<15$ & $0.60^{*}$ \\
$15-29$ & 0.45 \\
$30-44$ & 0.30 \\
$45-49$ & 0.15 \\
$50-54$ & 0.025 \\
$\geq 55$ & 0.00 \\
\hline \multicolumn{2}{l}{ Note: Karmini et al. (2020a); *Karmini et al. (2020b) }
\end{tabular}

Note: Karmini et al. (2020a); *Karmini et al. (2020b)

Where:

$P M_{i j}$ : profit margin;

$P_{i j} \quad: \operatorname{logs}$ price for each species at sawmill based on diameter class;

$P R$ : profit ratio;

$i \quad:$ an index for each species $(i=1,2,3,4, \ldots ., n)$;

$j \quad:$ an index for diameter class $(i=1,2,3,4, \ldots ., n)$.

The exchange rate was USD1.00 equal to IDR14,403.70 at 22 August 2021. The following formula is used to evaluated stumpage values:

$$
S_{i j}=\sum_{i=1}^{n} \sum_{j=1}^{k} V_{i j}\left(P_{i j}+C+P M\right)
$$

Where:

$S_{i j}$ : stumpage value for each species and diameter class (USD ha-1);

$V_{i j} \quad$ : volume of timber for each species and diameter class $\left(\mathrm{m}^{3}\right)$;

$P_{i j} \quad: \operatorname{logs}$ price for each species at sawmill based on diameter class (USD m ${ }^{-3}$ );

$C \quad$ : average logging cost (USD ha $\left.{ }^{-1}\right)$;

$P M_{i j}$ : profit margin (USD m ${ }^{-3}$ );

$i \quad:$ an index for each species $(i=1,2,3,4, \ldots, n)$;

$j \quad:$ an index for diameter class $(i=1,2,3,4, \ldots, n)$.

\section{RESULTS AND DISCUSSION}

Ecological characteristics of 50-years secondary forest Diameter at breast height (DBH) and height distributions

The diameter distribution is in the form of an inverted $\mathbf{J}$ curve with a high number of individuals in the low diameter class and a low number of individuals in the high 
diameter class. A similar pattern of diameter distribution in various types of tropical secondary forest was also found in many studies (e.g., Feldpausch et al. 2007; Alvarez-Yépiz et al. 2008; Karmini et al. 2020a, 2020b). Eighty percent of the diameters of the trees belong to the DBH class of 5.0$15.0 \mathrm{~cm}$ (350 trees), followed by the DBH class of 15.1 $25.0 \mathrm{~cm}$ (63 trees or $14 \%), \mathrm{DBH}$ class of 25.1-35 $0.0(19$ trees or $4 \%$ ), and DBH class $>35.0 \mathrm{~cm}$ (5 trees or $1 \%$ ) (Figure 3).

Based on the height class, the trees belonged to class 0$5.0 \mathrm{~m}$ (108 trees or $25 \%)$, class $5.1-10.0 \mathrm{~m}$ (203 trees or $46 \%$ ), and class $10.1-15.0 \mathrm{~m}$ (110 trees or $25 \%)$. A very small portion of higher trees with a total of 11 and 5 trees was included in the $15.1-20.0 \mathrm{~m} \mathrm{(3 \% )}$ and $>20.0 \mathrm{~m} \mathrm{(1 \% )}$ as shown in Figure 4. The distribution of height class shows a slightly skewed toward positive pattern (Ohtsuka 2002). As early successional pioneer species began to disappear and long-lived pioneer species emerged (Norden et al. 2009), it was shown that intermediate-aged secondary forest between 30 and 50 years had lower structural complexity based on tree height and average stem diameter (Otuoma et al. 2014). The light-demanding pioneer species have also disappeared in 20-year-old secondary forests (Karyati et al. 2018). During the succession process there was a rapid increase in height and the stand size increased rapidly where the tree canopy was taller, thicker, and the canopy larger (Matsuo et al. 2021). Most late-successional species growing in old secondary forests can grow long enough to allow them to reach tree heights and average trunk DBH equal to or greater than trees in mature plantations (Otuoma et al. 2014).

\section{Species richness, density, basal area, and volume}

The vegetation survey of woody trees with a DBH of more than $5 \mathrm{~cm}$ in the 50 years secondary forest recorded 437 trees, 38 species, 30 genera, and 19 families. Table 3 presents the species, density, basal area, and volume of species in the study plot. The trees had DBH ranging from 5.1 to $56.3 \mathrm{~cm}$ with an average $\mathrm{DBH}$ of $11.5 \mathrm{~cm}$. Meanwhile, the tree height ranged between 2.0 and $25.0 \mathrm{~m}$ with an average height of $8.50 \mathrm{~m}$. The total basal area (BA) and volume of trees in the 50 years secondary forest were $15.36 \mathrm{~m}^{2} \mathrm{ha}^{-1}$ and $122 \mathrm{~m}^{3} \mathrm{ha}^{-1}$, respectively. The smaller total BA (9.75 and $9.44 \mathrm{~m}^{2} \mathrm{ha}^{-1}$ ) and volume (91.97 and $\left.76.86 \mathrm{~m}^{3} \mathrm{ha}^{-1}\right)$ were reported in abandoned land after shifting cultivation and traditional garden (Karmini et al. $2020 \mathrm{a} ; 2020 \mathrm{~b})$. The three dominant species in terms of total $\mathrm{BA}$ and volume were Artocarpus elasticus (total BA=3.28 $\mathrm{m}^{2} \mathrm{ha}^{-1}$ and volume $\left.=35.68 \mathrm{~m}^{3} \mathrm{ha}^{-1}\right)$, Mangifera motleyana (total $\mathrm{BA}=2.88 \mathrm{~m}^{2} \mathrm{ha}^{-1}$ and volume $=19.77 \mathrm{~m}^{3} \mathrm{ha}^{-1}$ ), and Symplocos fasciculate (total $\mathrm{BA}=1.85 \mathrm{~m}^{2} \mathrm{ha}^{-1}$ and volume $\left.=12.25 \mathrm{~m}^{3} \mathrm{ha}^{-1}\right)$. These three tree species contributed more than $50 \%$ of the total basal area and volume. The other four species of Vernonia arborea, Ficus septica, Talipariti simile, and Durio sp. had a total volume of more than $3 \%$.

The studied plots were dominated by fast-growing species such as Artocarpus dadah, Artocarpus tamaran, Artocarpus elasticus, Macaranga gigantea, Artocarpus heterophyllus, Macaranga motleyana, Macaranga sp., dan
Macaranga tanarius. In other studies, similar common fast growing species were also found, including Macaranga spp and Artocarpus spp. in 5 and 10 years old abandoned lands (Karyati et al. 2018), abandoned land after shifting cultivation (Karmini et al. 2020a), and abandoned land after traditional garden (Karmini et al. 2020b) as well as seedlings and saplings in 3, 5, 10, and 20 years of fallow lands (Karyati et al. 2013). Hevea brasiliensis and Ceiba pentandra are remnants of plantation crops grown at this location. Meanwhile, Durio sp. is a native plant of Kalimantan.

The three families of 19 families with the high basal area and volume at the study site were Moraceae, Euphorbiaceae, and Symplocaceae as shown in Table 4. The total basal area and volume of woody trees belonging to the three families is more than $70 \%$. Other families that are also quite dominant are Malvaceae, Asteraceae, Fabaceae, and Phyllanthaceae. Total tree species belonging to Moraceae, Euphorbiaceae, and Symplocaceae were 7, 8, and 1 respectively. This shows the trees in these families play an important role in plant structure and composition at the study site. Three tree species belonged to Malvaceae and Phyllanthaceae. Meanwhile, Cannabaceae and Fabaceae had two tree species. The other 12 families are only consisting of 1 tree species. Another study found the family consisting of the highest number of species in secondary forest of uneven age is Moraceae, followed by Apocynaceae, Euphorbiaceae, Fabaceae, Rubiaceae, Sapindaceae, and Sterculiaceae (Aghimien et al. 2016).

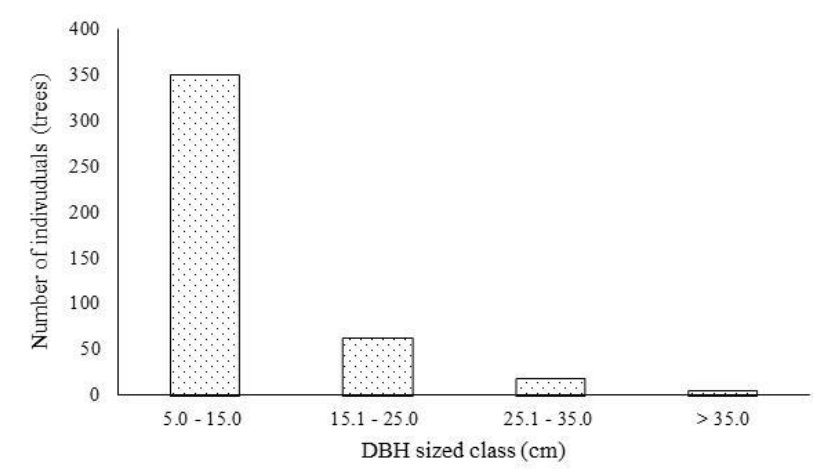

Figure 3. Distributions of diameter at breast height (DBH) of tree species in 0.4 ha of 50 years old secondary forest

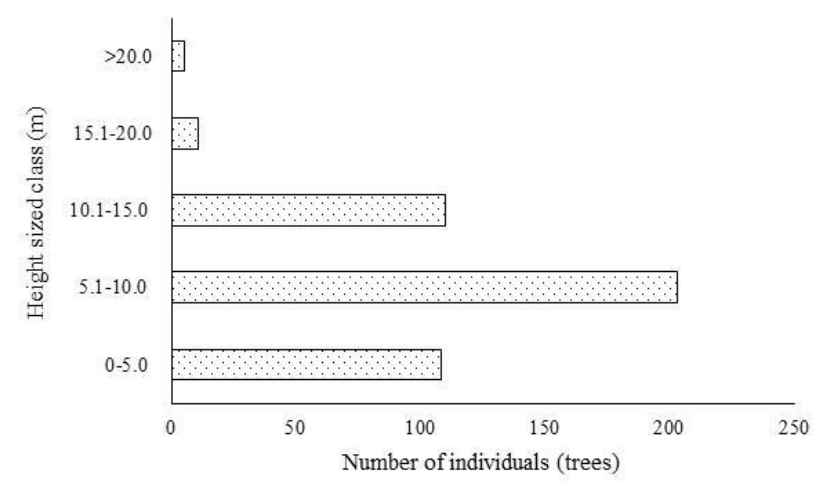

Figure 4. Distributions of height of tree species in 0.4 ha of 50 years old secondary forest 
Table 3. Species richness, density, basal area, and volume of species (DBH of $\geq 5 \mathrm{~cm}$ ) in the study plot

\begin{tabular}{|c|c|c|c|c|c|c|c|}
\hline \multirow{2}{*}{ Species } & \multirow{2}{*}{$\mathbf{N}$} & \multirow{2}{*}{$\begin{array}{l}\text { Average of } \\
\text { DBH }(\mathbf{c m})\end{array}$} & \multirow{2}{*}{$\begin{array}{l}\text { Average of } \\
\text { height }(\mathrm{m})\end{array}$} & \multicolumn{2}{|c|}{ BA $\left(\mathbf{m}^{2} h^{-1}\right)$} & \multicolumn{2}{|c|}{ Volume $\left(\mathrm{m}^{3} \mathrm{ha}^{-1}\right)$} \\
\hline & & & & Total & $\%$ & Total & $\%$ \\
\hline Artocarpus elasticus & 27 & 21.9 & 13.2 & 3.28 & 21.33 & 35.68 & 29.23 \\
\hline Macaranga motleyana & 103 & 11.2 & 9.3 & 2.88 & 18.76 & 19.77 & 16.20 \\
\hline Symplocos fasciculate & 51 & 11.3 & 6.7 & 1.85 & 12.04 & 12.25 & 10.04 \\
\hline Vernonia arborea & 8 & 21.0 & 13.4 & 0.83 & 5.40 & 8.48 & 6.95 \\
\hline Ficus septica & 29 & 11.6 & 7.5 & 0.93 & 6.03 & 5.61 & 4.59 \\
\hline Talipariti simile & 10 & 12.2 & 9.1 & 0.48 & 3.11 & 4.94 & 4.04 \\
\hline Durio sp. & 1 & 38.2 & 25.0 & 0.29 & 1.86 & 4.65 & 3.81 \\
\hline Archidendron pauciflorum & 10 & 15.2 & 9.2 & 0.52 & 3.37 & 3.34 & 2.73 \\
\hline Bridelia stipularis & 18 & 11.1 & 8.7 & 0.48 & 3.13 & 3.22 & 2.64 \\
\hline Derris caudatilimba & 16 & 10.3 & 9.0 & 0.41 & 2.70 & 2.98 & 2.44 \\
\hline Macaranga gigantea & 9 & 14.1 & 8.9 & 0.41 & 2.66 & 2.74 & 2.24 \\
\hline Artocarpus tamaran & 6 & 11.0 & 7.6 & 0.22 & 1.43 & 1.91 & 1.56 \\
\hline Ficus uncinata & 34 & 7.1 & 7.0 & 0.37 & 2.38 & 1.75 & 1.43 \\
\hline Nephelium lappaceum & 2 & 18.8 & 12.5 & 0.16 & 1.06 & 1.67 & 1.37 \\
\hline Ecclinusa ramiflora & 8 & 11.1 & 11.5 & 0.20 & 1.31 & 1.58 & 1.30 \\
\hline Glochidion obscurum & 1 & 27.0 & 15.5 & 0.14 & 0.94 & 1.45 & 1.19 \\
\hline Macaranga tanarius & 12 & 8.5 & 7.6 & 0.20 & 1.31 & 1.36 & 1.11 \\
\hline Hevea brasiliensis & 11 & 9.9 & 8.9 & 0.22 & 1.44 & 1.32 & 1.08 \\
\hline Artocarpus dadah & 14 & 10.0 & 6.9 & 0.28 & 1.85 & 1.29 & 1.05 \\
\hline Rhodamnia sp. & 6 & 12.3 & 9.7 & 0.19 & 1.22 & 1.20 & 0.98 \\
\hline Vitex pinnata & 14 & 8.7 & 6.1 & 0.23 & 1.48 & 0.97 & 0.80 \\
\hline Homalanthus populneus & 8 & 7.9 & 6.8 & 0.12 & 0.76 & 0.71 & 0.58 \\
\hline Aleurites moluccanus & 3 & 10.9 & 8.7 & 0.08 & 0.55 & 0.47 & 0.39 \\
\hline Macaranga sp. & 1 & 19.1 & 9.5 & 0.07 & 0.47 & 0.44 & 0.36 \\
\hline Artocarpus heterophyllus & 5 & 9.7 & 4.6 & 0.10 & 0.65 & 0.37 & 0.30 \\
\hline Mallotus paniculatus & 4 & 8.8 & 8.3 & 0.06 & 0.41 & 0.34 & 0.28 \\
\hline Nauclea xanthoxylon & 2 & 13.2 & 5.5 & 0.07 & 0.45 & 0.25 & 0.21 \\
\hline Litsea firma & 1 & 12.7 & 11.0 & 0.03 & 0.21 & 0.23 & 0.19 \\
\hline Melicope lunu-ankenda & 3 & 8.2 & 8.0 & 0.04 & 0.27 & 0.22 & 0.18 \\
\hline Garcinia intermedia & 2 & 8.6 & 9.0 & 0.03 & 0.19 & 0.18 & 0.14 \\
\hline Ficus aurata & 3 & 7.7 & 5.3 & 0.04 & 0.25 & 0.17 & 0.14 \\
\hline Baccaurea sp. & 3 & 7.1 & 7.0 & 0.03 & 0.20 & 0.16 & 0.13 \\
\hline Ceiba pentandra & 7 & 6.3 & 2.9 & 0.06 & 0.36 & 0.10 & 0.09 \\
\hline Cratoxylum arborescens & 1 & 10.8 & 6.0 & 0.02 & 0.15 & 0.09 & 0.07 \\
\hline Gironniera celtidifolia & 1 & 8.3 & 10.0 & 0.01 & 0.09 & 0.09 & 0.07 \\
\hline Alstonia scholaris & 1 & 8.6 & 6.0 & 0.01 & 0.09 & 0.06 & 0.05 \\
\hline Dillenia excelsa & 1 & 6.4 & 5.0 & 0.01 & 0.05 & 0.03 & 0.02 \\
\hline Trema orientalis & 1 & 5.1 & 3.5 & 0.01 & 0.03 & 0.01 & 0.01 \\
\hline Total & 437.0 & 461.8 & 330.3 & 15.36 & 100.00 & 122.07 & 100.00 \\
\hline Average & 11.5 & 12.2 & 8.7 & 0.40 & & 3.21 & \\
\hline Minimum & 1.0 & 5.1 & 2.9 & 0.01 & & 0.01 & \\
\hline Maximum & 103.0 & 38.2 & 25.0 & 3.28 & & 35.68 & \\
\hline
\end{tabular}

Note: N: number of individuals (trees), DBH: diameter at breast height, BA: basal area

\section{Importance value index (IVi)}

Most of the dominant tree species in terms of basal area and volume are also dominant species based on the importance value index (IVi). The IVi of tree in the studied site is shown in Table 5. The five most dominant species in terms of IVi were Macaranga motleyana (IVi of 50.95) followed by Artocarpus elasticus (IVi of 34.41), Symplocos fasciculata (IVi of 31.46), Ficus septica (IVi of 20.43), and Ficus uncinata (IVi of 15.33). The other three species of Derris caudatilimba (IVi of 12.40), Bridelia stipularis (IVi of 10.70), and Archidendron pauciflorum (IVi of 9.97) were also dominant in this site. Seven of 38 species recorded had an IVi of more than 10.00, 9 species had an IVi of 5.00-10.00 and the other 22 species have an IVi of less than 5.00.

Moraceae and Euphorbiaceae had the family important value (FIV) of 86.79 (Table 6). Tree species including
Moraceae are Artocarpus dadah, Artocarpus elasticus, Artocarpus heterophyllus, Artocarpus tamaran, Ficus aurata, Ficus septica, and Ficus uncinata. Meanwhile Euphorbiaceae consists of Aleurites moluccanus, Hevea brasiliensis, Homalanthus populneus, Macaranga gigantea, Macaranga motleyana, Macaranga sp., Macaranga tanarius, and Mallotus paniculatus. Similar results of prior studies also report that Moraceae and Euphorbiaceae are the important and dominant families in tropical lands (Danquah et al. 2011; Karyati et al. 2018; Karmini et al. 2020a; Karmini et al. 2020b). The floristic difference between forest fringes and the core of the forest is low tree diversity and distribution. The forest fringe plant community is dominated by Dipterocarpaceae and Euphorbiaceae (Jana and Jusoh 2021). 
Table 4. Family, density, basal area, and volume of family (DBH of $\geq 5 \mathrm{~cm}$ ) in the study plot

\begin{tabular}{|c|c|c|c|c|c|c|c|}
\hline \multirow{2}{*}{ Family } & \multirow{2}{*}{$\mathbf{N}$} & \multirow{2}{*}{$\begin{array}{c}\text { Average of DBH } \\
(\mathrm{cm})\end{array}$} & \multirow{2}{*}{$\begin{array}{l}\text { Average of height } \\
\text { (m) }\end{array}$} & \multicolumn{2}{|c|}{ BA $\left(\mathbf{m}^{2} h^{-1}\right)$} & \multicolumn{2}{|c|}{ Volume $\left(\mathrm{m}^{3} \mathrm{ha}^{-1}\right)$} \\
\hline & & & & Total & $\%$ & Total & $\%$ \\
\hline Moraceae & 118 & 12.3 & 8.4 & 5.21 & 33.93 & 46.76 & 38.31 \\
\hline Euphorbiaceae & 151 & 10.9 & 9.0 & 4.05 & 26.37 & 27.15 & 22.25 \\
\hline Symplocaceae & 51 & 11.3 & 6.7 & 1.85 & 12.04 & 12.25 & 10.04 \\
\hline Malvaceae & 18 & 11.3 & 7.6 & 0.82 & 5.34 & 9.70 & 7.94 \\
\hline Asteraceae & 8 & 21.0 & 13.4 & 0.83 & 5.40 & 8.48 & 6.95 \\
\hline Fabaceae & 26 & 12.2 & 9.1 & 0.93 & 6.07 & 6.32 & 5.18 \\
\hline Phyllanthaceae & 22 & 11.3 & 8.7 & 0.66 & 4.27 & 4.83 & 3.96 \\
\hline Sapindaceae & 2 & 18.8 & 12.5 & 0.16 & 1.06 & 1.67 & 1.37 \\
\hline Sapotaceae & 8 & 11.1 & 11.5 & 0.20 & 1.31 & 1.58 & 1.30 \\
\hline Myrtaceae & 6 & 12.3 & 9.7 & 0.19 & 1.22 & 1.20 & 0.98 \\
\hline Lamiaceae & 14 & 8.7 & 6.1 & 0.23 & 1.48 & 0.97 & 0.80 \\
\hline Rubiaceae & 2 & 13.2 & 5.5 & 0.07 & 0.45 & 0.25 & 0.21 \\
\hline Lauraceae & 1 & 12.7 & 11.0 & 0.03 & 0.21 & 0.23 & 0.19 \\
\hline Rutaceae & 3 & 8.2 & 8.0 & 0.04 & 0.27 & 0.22 & 0.18 \\
\hline Clusiaceae & 2 & 8.6 & 9.0 & 0.03 & 0.19 & 0.18 & 0.14 \\
\hline Cannabaceae & 2 & 6.7 & 6.8 & 0.02 & 0.12 & 0.10 & 0.08 \\
\hline Hypericaceae & 1 & 10.8 & 6.0 & 0.02 & 0.15 & 0.09 & 0.07 \\
\hline Apocynaceae & 1 & 8.6 & 6.0 & 0.01 & 0.09 & 0.06 & 0.05 \\
\hline Dilleniaceae & 1 & 6.4 & 5.0 & 0.01 & 0.05 & 0.03 & 0.02 \\
\hline Total & 437.0 & 216.2 & 159.8 & 15.36 & 100.00 & 122.07 & 100.00 \\
\hline Average & 23.0 & 11.4 & 8.4 & 0.81 & & 6.42 & \\
\hline Minimum & 1.0 & 6.4 & 5.0 & 0.01 & & 0.03 & \\
\hline Maximum & 151.0 & 21.0 & 13.4 & 5.21 & & 46.76 & \\
\hline
\end{tabular}

Note: N: number of individuals (trees), DBH: diameter at breast height, BA: basal area.

Table 5. Importance value index (IVi) of trees $(\mathrm{DBH}$ of $>5 \mathrm{~cm}$ ) in 0.4 hectare of the study plot

\begin{tabular}{|c|c|c|c|c|c|}
\hline Species & Family & RF (\%) & $\operatorname{Rd}(\%)$ & RD $(\%)$ & IVi $(\%)$ \\
\hline Macaranga motleyana & Euphorbiaceae & 8.62 & 23.57 & 18.76 & 50.95 \\
\hline Artocarpus elasticus & Moraceae & 6.90 & 6.18 & 21.33 & 34.41 \\
\hline Symplocos fasciculata & Symplocaceae & 7.76 & 11.67 & 12.04 & 31.46 \\
\hline Ficus septica & Moraceae & 7.76 & 6.64 & 6.03 & 20.43 \\
\hline Ficus uncinata & Moraceae & 5.17 & 7.78 & 2.38 & 15.33 \\
\hline Derris caudatilimba & Fabaceae & 6.03 & 3.66 & 2.70 & 12.40 \\
\hline Bridelia stipularis & Phyllanthaceae & 3.45 & 4.12 & 3.13 & 10.70 \\
\hline Archidendron pauciflorum & Fabaceae & 4.31 & 2.29 & 3.37 & 9.97 \\
\hline Vernonia arborea & Asteraceae & 1.72 & 1.83 & 5.40 & 8.95 \\
\hline Macaranga gigantea & Euphorbiaceae & 3.45 & 2.06 & 2.66 & 8.17 \\
\hline Vitex pinnata & Lamiaceae & 3.45 & 3.20 & 1.48 & 8.13 \\
\hline Talipariti simile & Malvaceae & 2.59 & 2.29 & 3.11 & 7.98 \\
\hline Macaranga tanarius & Euphorbiaceae & 3.45 & 2.75 & 1.31 & 7.51 \\
\hline Artocarpus dadah & Moraceae & 1.72 & 3.20 & 1.85 & 6.77 \\
\hline Homalanthus populneus & Euphorbiaceae & 3.45 & 1.83 & 0.76 & 6.04 \\
\hline Hevea brasiliensis & Euphorbiaceae & 1.72 & 2.52 & 1.44 & 5.68 \\
\hline Ecclinusa ramiflora & Sapotaceae & 1.72 & 1.83 & 1.31 & 4.87 \\
\hline Artocarpus tamaran & Moraceae & 1.72 & 1.37 & 1.43 & 4.53 \\
\hline Rhodamnia sp. & Myrtaceae & 1.72 & 1.37 & 1.22 & 4.31 \\
\hline Mallotus paniculatus & Euphorbiaceae & 2.59 & 0.92 & 0.41 & 3.91 \\
\hline Melicope lunu-ankenda & Rutaceae & 2.59 & 0.69 & 0.27 & 3.54 \\
\hline Nephelium lappaceum & Sapindaceae & 1.72 & 0.46 & 1.06 & 3.25 \\
\hline Aleurites moluccanus & Euphorbiaceae & 1.72 & 0.69 & 0.55 & 2.96 \\
\hline Durio sp. & Malvaceae & 0.86 & 0.23 & 1.86 & 2.96 \\
\hline Ceiba pentandra & Malvaceae & 0.86 & 1.60 & 0.36 & 2.83 \\
\hline Ficus aurata & Moraceae & 1.72 & 0.69 & 0.25 & 2.66 \\
\hline Artocarpus heterophyllus & Moraceae & 0.86 & 1.14 & 0.65 & 2.66 \\
\hline Baccaurea sp. & Phyllanthaceae & 1.72 & 0.69 & 0.20 & 2.61 \\
\hline Glochidion obscurum & Phyllanthaceae & 0.86 & 0.23 & 0.94 & 2.03 \\
\hline Nauclea xanthoxylon & Rubiaceae & 0.86 & 0.46 & 0.45 & 1.77 \\
\hline Macaranga sp. & Euphorbiaceae & 0.86 & 0.23 & 0.47 & 1.56 \\
\hline Garcinia intermedia & Clusiaceae & 0.86 & 0.46 & 0.19 & 1.51 \\
\hline Litsea firma & Lauraceae & 0.86 & 0.23 & 0.21 & 1.30 \\
\hline Cratoxylum arborescens & Hypericaceae & 0.86 & 0.23 & 0.15 & 1.24 \\
\hline Alstonia scholaris & Apocynaceae & 0.86 & 0.23 & 0.09 & 1.19 \\
\hline Gironniera celtidifolia & Cannabaceae & 0.86 & 0.23 & 0.09 & 1.18 \\
\hline Dillenia excelsa & Dilleniaceae & 0.86 & 0.23 & 0.05 & 1.14 \\
\hline Trema orientalis & Cannabaceae & 0.86 & 0.23 & 0.03 & 1.12 \\
\hline Total & & 100.00 & 100.00 & 100.00 & 300.00 \\
\hline
\end{tabular}

Note: RF: relative frequency, Rd: relative density, RD: relative dominance, IVi: importance value index. 
Table 6. Family Importance Value (FIV) of trees (DBH of $>5$ $\mathrm{cm})$ in 0.4 hectare of the study plot

\begin{tabular}{lllll}
\hline Species & RF & Rd & RD & FIV \\
\hline Moraceae & 25.86 & 27.00 & 33.93 & 86.79 \\
Euphorbiaceae & 25.86 & 34.55 & 26.37 & 86.79 \\
Symplocaceae & 7.76 & 11.67 & 12.04 & 31.46 \\
Fabaceae & 10.34 & 5.95 & 6.07 & 22.36 \\
Phyllanthaceae & 6.03 & 5.03 & 4.27 & 15.34 \\
Malvaceae & 4.31 & 4.12 & 5.34 & 13.77 \\
Asteraceae & 1.72 & 1.83 & 5.40 & 8.95 \\
Lamiaceae & 3.45 & 3.20 & 1.48 & 8.13 \\
Sapotaceae & 1.72 & 1.83 & 1.31 & 4.87 \\
Myrtaceae & 1.72 & 1.37 & 1.22 & 4.31 \\
Rutaceae & 2.59 & 0.69 & 0.27 & 3.54 \\
Sapindaceae & 1.72 & 0.46 & 1.06 & 3.25 \\
Cannabaceae & 1.72 & 0.46 & 0.12 & 2.30 \\
Rubiaceae & 0.86 & 0.46 & 0.45 & 1.77 \\
Clusiaceae & 0.86 & 0.46 & 0.19 & 1.51 \\
Lauraceae & 0.86 & 0.23 & 0.21 & 1.30 \\
Hypericaceae & 0.86 & 0.23 & 0.15 & 1.24 \\
Apocynaceae & 0.86 & 0.23 & 0.09 & 1.19 \\
Dilleniaceae & 0.86 & 0.23 & 0.05 & 1.14 \\
Total & 100.00 & 100.00 & 100.00 & 300.00 \\
\hline
\end{tabular}

Note: RF: relative frequency, Rd: relative density, RD: relative dominance, FIV: family importance value

Table 7. Diversity indices of trees with DBH of $\geq 5 \mathrm{~cm}$ in the study plot

\begin{tabular}{lc}
\hline Diversity indices & Value \\
\hline Shannon-Wiener diversity index $\left(H^{\prime}\right)$ & 1.33 \\
Simpson dominance index $\left(D_{s}\right)$ & 0.07 \\
Pielou evenness index $\left(J^{\prime}\right)$ & 0.84 \\
Margalef species richness $(R)$ & 6.09 \\
\hline Nare
\end{tabular}

Note: The values were calculated according to the 10 subplots sized $20 \mathrm{~m} \times 20 \mathrm{~m}$ each

\section{Species diversity}

The result of the analysis indicates that the secondary forest studied had an intermediate diversity index in terms of trees $\left(\mathrm{DBH}>5 \mathrm{~cm}\right.$ ) with $\mathrm{H}^{\prime} 1.33$ (Table 7). That is, the number of trees that grow in the research location is quite a lot. A high-growing species diversity represents a very complex community (Brower et al. 1990). The dominance index (Ds) of 0.07 in the study area included in the low criteria, indicates no dominant species in the area. The diversity index and dominance index are determined by the number of individuals of a species and the total number of individuals in an area. The 'high' evenness index category (J value' 0.84 ) indicated that the trees growing in the plot were evenly distributed. The evenness of plant species is determined by the diversity of species and the number of species in the area. The species richness index of 6.09 indicates that many tree species grow in this research location. Plant species richness is calculated based on the number of species in an area (Krebs 2001), the number of individuals of a species, and the density of existing plants.
Species richness indicates the number of species in an area, while evenness is a relative measure of the abundance of different species that make up the wealth of an area (Supriatna 2018). The results showed that high diversity $\left(\mathrm{H}^{\prime}\right)$, evenness $\left(\mathrm{J}^{\prime}\right)$, and richness $(\mathrm{R})$ tended to cause low dominance (Ds). Similar results were reported for the tree diversity index with $\mathrm{DBH}>5 \mathrm{~cm}$ in plots with $5,10,20$ years abandoned land (Karyati et al. 2018), abandoned land after shifting cultivation (Karmini et al. 2020a), and abandoned land after traditional gardening (Karmini et al. $2020 \mathrm{~b}$ ). In addition, due to the poor status of soil fertility in an area, a period of 50 years of abandoned land is not sufficient for lands to restore their vegetation conditions such as natural forests (Wasli et al. 2011). This is supported with the Brearley et al. (2004) study in Central Kalimantan Province, Indonesia that found Shannon-Wiener diversity index $\left(\mathrm{H}^{\prime}\right)$ at an old secondary forest and primary forest were 3.40 and 4.17 , respectively, that meant species diversity indices at an old secondary forest was lower than at primary forest.

\section{The economic value of 50 years secondary forest Logging costs}

In this study, the logging costs were the same for all tree species, i.e. USD69.43 $\mathrm{m}^{-3}$ (Table 8). The total logging costs of 38 species in this study location were

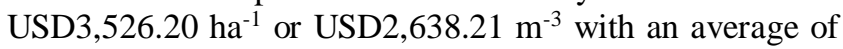
USD92.79 $\mathrm{ha}^{-1}$ or USD69.43 $\mathrm{m}^{-3}$ for each species. The total logging costs in this study were higher than that of other previous studies (Karmini et al. 2020a; Karmini et al. 2020b). According to Karyati et al. (2021), the factors that influence logging costs include topography, tree dominance and species, density, tree diameter, log volume, felling productivity, loggers' experience, work, and remuneration systems, management competence, and other factors.

\section{Prices of logs and lumber}

The results of this study (Table 9) show that the total logs price of 38 species was USD1,696.03 $\mathrm{m}^{-3}$ with an average of USD44.63 $\mathrm{m}^{-3}$ species ${ }^{-1}$. Meanwhile, the total lumber price of 38 tree species studied was USD3,801.11 $\mathrm{m}^{-3}$ with an average of USD100.03 $\mathrm{m}^{-3}$ species $^{-1}$. The lumber price of 10 tree species differed from one another while the lumber price of 28 other tree species was the same in the study location. A total of 13 tree species has the same logs price, which was USD20.83 $\mathrm{m}^{-3}$. There were three tree species (Vernonia arborea, Macaranga sp., and Glochidion obscurum) which had a log price of USD28.64 $\mathrm{m}^{-3}$. The total $\operatorname{logs}$ and lumber prices in this study was lower than the results of other previous studies (Karmini et al. 2020a, Karmini et al. 2020b). According to Karyati et al. (2021), the factors that determine the difference and the price of logs and lumber include tree species, tree diameter, wood quality, total tree individuals, harvesting cycle, supply, demand, use, price competition, substitute products, and other factors. 
Table 8. Logging costs of trees in 0.4 ha of 50 years old secondary forest in East Kalimantan, Indonesia

\begin{tabular}{|c|c|c|c|}
\hline \multirow{2}{*}{ Species } & \multirow{2}{*}{ Family } & \multicolumn{2}{|c|}{ Logging costs } \\
\hline & & USD $\mathrm{m}^{-3}$ & USD ha $^{-1}$ \\
\hline Artocarpus elasticus & Moraceae & 69.43 & $1,102.30$ \\
\hline Symplocos fasciculata & Symplocaceae & 69.43 & 498.68 \\
\hline Macaranga motleyana & Euphorbiaceae & 69.43 & 434.37 \\
\hline Vernonia arborea & Asteraceae & 69.43 & 283.25 \\
\hline Ficus septica & Moraceae & 69.43 & 163.43 \\
\hline Talipariti simile & Malvaceae & 69.43 & 152.20 \\
\hline Archidendron pauciflorum & Fabaceae & 69.43 & 105.46 \\
\hline Durio sp. & Malvaceae & 69.43 & 129.18 \\
\hline Macaranga gigantea & Euphorbiaceae & 69.43 & 83.85 \\
\hline Bridelia stipularis & Phyllanthaceae & 69.43 & 75.97 \\
\hline Derris caudatilimba & Fabaceae & 69.43 & 68.82 \\
\hline Artocarpus tamaran & Moraceae & 69.43 & 42.98 \\
\hline Ficus uncinata & Moraceae & 69.43 & 41.25 \\
\hline Nephelium lappaceum & Sapindaceae & 69.43 & 34.24 \\
\hline Glochidion obscurum & Phyllanthaceae & 69.43 & 32.41 \\
\hline Artocarpus dadah & Moraceae & 69.43 & 31.96 \\
\hline Hevea brasiliensis & Euphorbiaceae & 69.43 & 30.78 \\
\hline Macaranga tanarius & Euphorbiaceae & 69.43 & 30.53 \\
\hline Rhodamnia sp. & Myrtaceae & 69.43 & 26.43 \\
\hline Vitex pinnata & Lamiaceae & 69.43 & 25.59 \\
\hline Ecclinusa ramiflora & Sapotaceae & 69.43 & 22.69 \\
\hline Homalanthus populneus & Euphorbiaceae & 69.43 & 19.30 \\
\hline Aleurites moluccanus & Euphorbiaceae & 69.43 & 16.31 \\
\hline Macaranga sp. & Euphorbiaceae & 69.43 & 16.15 \\
\hline Artocarpus heterophyllus & Moraceae & 69.43 & 11.32 \\
\hline Nauclea xanthoxylon & Rubiaceae & 69.43 & 7.78 \\
\hline Mallotus paniculatus & Euphorbiaceae & 69.43 & 7.09 \\
\hline Ceiba pentandra & Malvaceae & 69.43 & 6.26 \\
\hline Melicope lunu-ankenda & Rutaceae & 69.43 & 4.66 \\
\hline Ficus aurata & Moraceae & 69.43 & 4.33 \\
\hline Litsea firma & Lauraceae & 69.43 & 3.59 \\
\hline Baccaurea sp. & Phyllanthaceae & 69.43 & 3.50 \\
\hline Garcinia intermedia & Clusiaceae & 69.43 & 3.29 \\
\hline Alstonia scholaris & Apocynaceae & 69.43 & 1.63 \\
\hline Cratoxylum arborescens & Hypericaceae & 69.43 & 1.63 \\
\hline Gironniera celtidifolia & Cannabaceae & 69.43 & 1.52 \\
\hline Dillenia excelsa & Dilleniaceae & 69.43 & 0.90 \\
\hline \multirow[t]{3}{*}{ Trema orientalis } & Cannabaceae & 69.43 & 0.57 \\
\hline & & $2,638.21$ & $3,526.20$ \\
\hline & & 6943 & 9279 \\
\hline
\end{tabular}

\section{Profit margin}

The profit margin in this study was assumed based on the profits obtained from the sale of timber. The data in Table 10 shows the profit margins from the sale of lumber obtained from 38 tree species. The total profit margin from the lumber sale of 38 tree species was USD391.39 $\mathrm{m}^{-3}$ or USD978.48 $\mathrm{ha}^{-1}$ with an average of USD10.30 $\mathrm{m}^{-3}$ or USD25.75 ha $^{-1}$ species $^{-1}$. The highest profit margin was obtained from the trade-in lumber of the Alstonia scholaris species. According to Karyati et al. (2021), the profit margin obtained from the trade-in logs and lumber is influenced by several factors, including the number of requests, the number of sales, the price of logs and lumber, tree diameter, production costs, pricing strategies, business management, and other factors.
Table 9. Prices of $\operatorname{logs}$ and lumber in 0.4 ha of 50 years old secondary forest in East Kalimantan, Indonesia

\begin{tabular}{llcc}
\hline Species & Family & $\begin{array}{c}\text { Logs price } \\
(\text { USD m }\end{array}$ & $\begin{array}{c}\text { Lumber } \\
\text { price } \\
\text { (USD m }\end{array}$ \\
\hline Alstonia scholaris & Apocynaceae & 333.25 & 833.12 \\
Durio sp. & Malvaceae & 206.54 & 295.06 \\
Cratoxylum arborescens & Hypericaceae & 97.20 & 242.99 \\
Artocarpus heterophyllus & Moraceae & 83.31 & 208.28 \\
Vitex pinnata & Lamiaceae & 63.87 & 159.68 \\
Artocarpus elasticus & Moraceae & 79.38 & 145.80 \\
Archidendron pauciflorum & Fabaceae & 65.96 & 138.85 \\
Nephelium lappaceum & Sapindaceae & 59.36 & 124.97 \\
Baccaurea sp. & Phyllanthaceae & 49.99 & 124.97 \\
Hevea brasiliensis & Euphorbiaceae & 28.72 & 69.43 \\
Vernonia arborea & Asteraceae & 28.64 & 52.07 \\
Macaranga sp. & Euphorbiaceae & 28.64 & 52.07 \\
Glochidion obscurum & Phyllanthaceae & 28.64 & 52.07 \\
Macaranga gigantea & Euphorbiaceae & 25.17 & 52.07 \\
Aleurites moluccanus & Euphorbiaceae & 23.43 & 52.07 \\
Talipariti simile & Malvaceae & 23.17 & 52.07 \\
Symplocos fasciculata & Symplocaceae & 23.13 & 52.07 \\
Bridelia stipularis & Phyllanthaceae & 22.56 & 52.07 \\
Ficus septica & Moraceae & 22.44 & 52.07 \\
Derris caudatilimba & Fabaceae & 22.29 & 52.07 \\
Artocarpus tamaran & Moraceae & 22.13 & 52.07 \\
Rhodamnia sp. & Myrtaceae & 22.13 & 52.07 \\
Macaranga motleyana & Euphorbiaceae & 22.04 & 52.07 \\
Homalanthus populneus & Euphorbiaceae & 21.80 & 52.07 \\
Macaranga tanarius & Euphorbiaceae & 21.48 & 52.07 \\
Ficus uncinata & Moraceae & 20.83 & 52.07 \\
Artocarpus dadah & Moraceae & 20.83 & 52.07 \\
Ecclinusa ramiflora & Sapotaceae & 20.83 & 52.07 \\
Ceiba pentandra & Malvaceae & 20.83 & 52.07 \\
Mallotus paniculatus & Euphorbiaceae & 20.83 & 52.07 \\
Ficus aurata & Moraceae & 20.83 & 52.07 \\
Melicope lunu-ankenda & Rutaceae & 20.83 & 52.07 \\
Nauclea xanthoxylon & Rubiaceae & 20.83 & 52.07 \\
Garcinia intermedia & Clusiaceae & 20.83 & 52.07 \\
Trema orientalis & Cannabaceae & 20.83 & 52.07 \\
Dillenia excelsa & Dilleniaceae & 20.83 & 52.07 \\
Gironniera celtidifolia & Cannabaceae & 20.83 & 52.07 \\
Litsea firma & Lauraceae & 20.83 & 52.07 \\
& & $1,696.03$ & $3,801.11$ \\
& 44.63 & 100.03 \\
\hline
\end{tabular}

Stumpage value

Economic assessment of the land can be done by assessing the stumpage growing on the land. The results of this study showed that the total stumpage value (consisting of 38 species) at the study site was USD1,091.76 ha-1. The average stumpage value was USD28.73 ha hpecies $^{-1}$. Figure 5 shows the stumpage value of each species at the study site. The stumpage value in this study was lower than the results of previous studies (Karmini et al. 2020a, Karmini et al. 2020b). The stumpage value is determined by the volume of timber for each species, the diameter of logs, the price of each species' logs at the sawmill, and the profit margin. Timber price is the dominant factor that determines the stumpage value. The more tree species that have a high selling value found on land, the higher the stumpage value. The results of this study can show that the stumpage at the study site has a very significant economic value. 
Table 10. Profit margin assumed from the sale of timber from 0.4 ha of 50 years old secondary forest in East Kalimantan, Indonesia

\begin{tabular}{|c|c|c|c|}
\hline \multirow{2}{*}{ Species } & \multirow{2}{*}{ Family } & \multicolumn{2}{|c|}{ Profit margin } \\
\hline & & USD $\mathrm{m}^{-3}$ & USD ha ${ }^{-1}$ \\
\hline Alstonia scholaris & Apocynaceae & 76.90 & 192.26 \\
\hline Durio sp. & Malvaceae & 47.66 & 119.16 \\
\hline Cratoxylum arborescens & Hypericaceae & 22.43 & 56.08 \\
\hline Artocarpus heterophyllus & Moraceae & 19.23 & 48.06 \\
\hline Artocarpus elasticus & Moraceae & 18.32 & 45.79 \\
\hline Archidendron pauciflorum & Fabaceae & 15.22 & 38.05 \\
\hline Vitex pinnata & Lamiaceae & 14.74 & 36.85 \\
\hline Nephelium lappaceum & Sapindaceae & 13.70 & 34.25 \\
\hline Baccaurea sp. & Phyllanthaceae & 11.54 & 28.84 \\
\hline Hevea brasiliensis & Euphorbiaceae & 6.63 & 16.57 \\
\hline Vernonia arborea & Asteraceae & 6.61 & 16.52 \\
\hline Macaranga sp. & Euphorbiaceae & 6.61 & 16.52 \\
\hline Glochidion obscurum & Phyllanthaceae & 6.61 & 16.52 \\
\hline Macaranga gigantea & Euphorbiaceae & 5.81 & 14.52 \\
\hline Aleurites moluccanus & Euphorbiaceae & 5.41 & 13.52 \\
\hline Talipariti simile & Malvaceae & 5.35 & 13.37 \\
\hline Symplocos fasciculata & Symplocaceae & 5.34 & 13.34 \\
\hline Bridelia stipularis & Phyllanthaceae & 5.21 & 13.02 \\
\hline Ficus septica & Moraceae & 5.18 & 12.95 \\
\hline Derris caudatilimba & Fabaceae & 5.14 & 12.86 \\
\hline Rhodamnia sp. & Myrtaceae & 5.11 & 12.77 \\
\hline Artocarpus tamaran & Moraceae & 5.11 & 12.77 \\
\hline Macaranga motleyana & Euphorbiaceae & 5.09 & 12.72 \\
\hline Homalanthus populneus & Euphorbiaceae & 5.03 & 12.58 \\
\hline Macaranga tanarius & Euphorbiaceae & 4.96 & 12.39 \\
\hline Ceiba pentandra & Malvaceae & 4.81 & 12.02 \\
\hline Ficus aurata & Moraceae & 4.81 & 12.02 \\
\hline Trema orientalis & Cannabaceae & 4.81 & 12.02 \\
\hline Ficus uncinata & Moraceae & 4.81 & 12.02 \\
\hline Artocarpus dadah & Moraceae & 4.81 & 12.02 \\
\hline Dillenia excelsa & Dilleniaceae & 4.81 & 12.02 \\
\hline Nauclea xanthoxylon & Rubiaceae & 4.81 & 12.02 \\
\hline Ecclinusa ramiflora & Sapotaceae & 4.81 & 12.02 \\
\hline Melicope lunu-ankenda & Rutaceae & 4.81 & 12.02 \\
\hline Mallotus paniculatus & Euphorbiaceae & 4.81 & 12.02 \\
\hline Garcinia intermedia & Clusiaceae & 4.81 & 12.02 \\
\hline Gironniera celtidifolia & Cannabaceae & 4.81 & 12.02 \\
\hline Litsea firma & Lauraceae & 4.81 & 12.02 \\
\hline & & 391.39 & 978.48 \\
\hline & & 1030 & 2575 \\
\hline
\end{tabular}

East Kalimantan has a lot of 50 years old secondary forests that is rich in biodiversity. The 50 years old secondary forests in East Kalimantan have ecological and economic characteristics. As many as $14 \%$ of trees in the 50 years old secondary forests have diameters at breast height between 15.1-25.0 cm and most trees (40\%) in there have height in class $5.1-10.0 \mathrm{~m}$. The 50 years old secondary forest has approximately 437 trees, 38 species, 30 genera, and 19 families with the total basal area and volume are around $15.36 \mathrm{~m}^{2} \mathrm{ha}^{-1}$ dan $122.07 \mathrm{~m}^{3} \mathrm{ha}^{-1}$. The most dominant families are Moraceae and Euphorbiaceace with an important value (FIV) of 86.79 and the three most dominant species were Macaranga motleyana (IVi of 50.95), Artocarpus elasticus (IVi of 34.41), and Symplocos fasciculata (IVi of 31.46). The trees in the 50 years old secondary forest have a diversity index of 1.33 , the dominance index of 0.07 , evenness index of 0.37 , and species richness of 6.09 . The economic values of 50 years old secondary forest could be seen from total and average values of logging costs (USD2,638.21 m $\mathrm{m}^{-3}$ and USD69.43 $\mathrm{m}-3$ ), $\operatorname{logs}$ price (USD1,696.03 $\mathrm{m}^{-3}$ and USD44.63 $\mathrm{m}^{-3}$ ), lumber price (USD3,801.11 $\mathrm{m}^{-3}$ and USD100.03 $\mathrm{m}^{-3}$ ), profit margin $\left(391.39 \mathrm{~m}^{-3}\right.$ and $\left.10.30 \mathrm{~m}^{-3}\right)$, stumpage value (usd1,091.76 ha ${ }^{-1}$ and usd28.73 ha- species $^{-1}$ ). Because of its ecological and economic values, 50 years old secondary forest must be preserved so that its ecological and economic values will continue to increase. The use of 50 years old secondary forest can be done with give attention to maintain and increase biodiversity.

\section{ACKNOWLEDGEMENTS}

The authors express their gratitude and highest appreciation to Ministry of Education, Culture, Research and Technology for Hibah Penelitian Dasar Unggulan Perguruan Tinggi Contract No.: 036/SP2H/LT/DRPM/2021 for funding this research. We thank the family of Mr. Nanang Helmi, who owns the land for the permission to carry out this research and fellow students for the assistance during the field work.

\section{REFERENCES}

Aghimien EV, Osho JSA, Hauser S, Deni B, Ade-Oni VD, Oboite FO. 2016. Growth and yield models for uneven-aged secondary forest in IITA, Ibadan, Nigeria. Forest Res 5 (2): 1-13. DOI: 10.4172/21689776.1000173

Álvarez-Yépiz JC, Martínez-Yrízar A, Búrquez A, Lindquist C. 2008. Variation in vegetation structure and soil properties related to land use history of old-growth and secondary tropical dry forests in Northwestern Mexico. For Ecol Manag 256: 355-366. DOI:10.1016/j.foreco.2008.04.049

Borges ER, Dexter KG, Pyles MV, Bueno ML, dos Santos RM, Fontes MAL, Carvalho FA. 2021. The interaction of land-use history and tree species diversity in driving variation in the aboveground biomass of urban versus non-urban tropical forests. Ecol Indic 129: 1-10. DOI: 10.1016/j.ecolind.2021.107915

Brearley FQ, Prajadinata S, Kidd PS, Proctor J, Suriantata. 2004. Structure and floristics of an old secondary rain forest in Central Kalimantan, Indonesia, and a comparison with adjacent primary forest. For Ecol Manag 195 (3): 385-397. DOI: 10.1016/j.foreco.2004.02.048

Brower JE, Zar JH, Von Ende CN. 1990. Field and Laboratory Methods for General Ecology, 3rd Ed. Wm. C. Brown Publishers, USA.

Chen X, Wang X, Li J, Kang D. 2020. Species diversity of primary and secondary forests in Wanglang Nature Reserve. Global Ecol Conserv 22: 1-7. DOI: 10.1016/j.gecco.2020.e01022

Dahalan MP. 2011. Spesies Composition, Stand Structure, Biomass and Economic Valuation of 2-ha Plots of Dipterocarp Forest of Different Geological Formation in Langkawi Island. Universiti Sains Malaysia, Pulau Pinang, Malaysia.

Danquah JA, Appiah M, Ari P. 2011. Comparison of post-fire planted and natural dry semi deciduous forest communities in Ghana. Afr J Agric Res 6 (23): 5266-5277. DOI: 10.5897/AJAR11.82

Fachrul MF. 2007. Bioecology Sampling Method. Bumi Aksara, Jakarta. [Indonesian]

Husch B, Miller CI, Beers TW. 1982. Forest Mensuration. John Wiley and Sons Publishing, New York.

Jana CL, Jusoh I. 2021. Structure and tree species composition of forest fringe of a forest fragment in an oil palm plantation at Suai, Sarawak, Malaysian Borneo. Biodiversitas 22 (7): 3013-3019. DOI: 10.13057/biodiv/d220755 


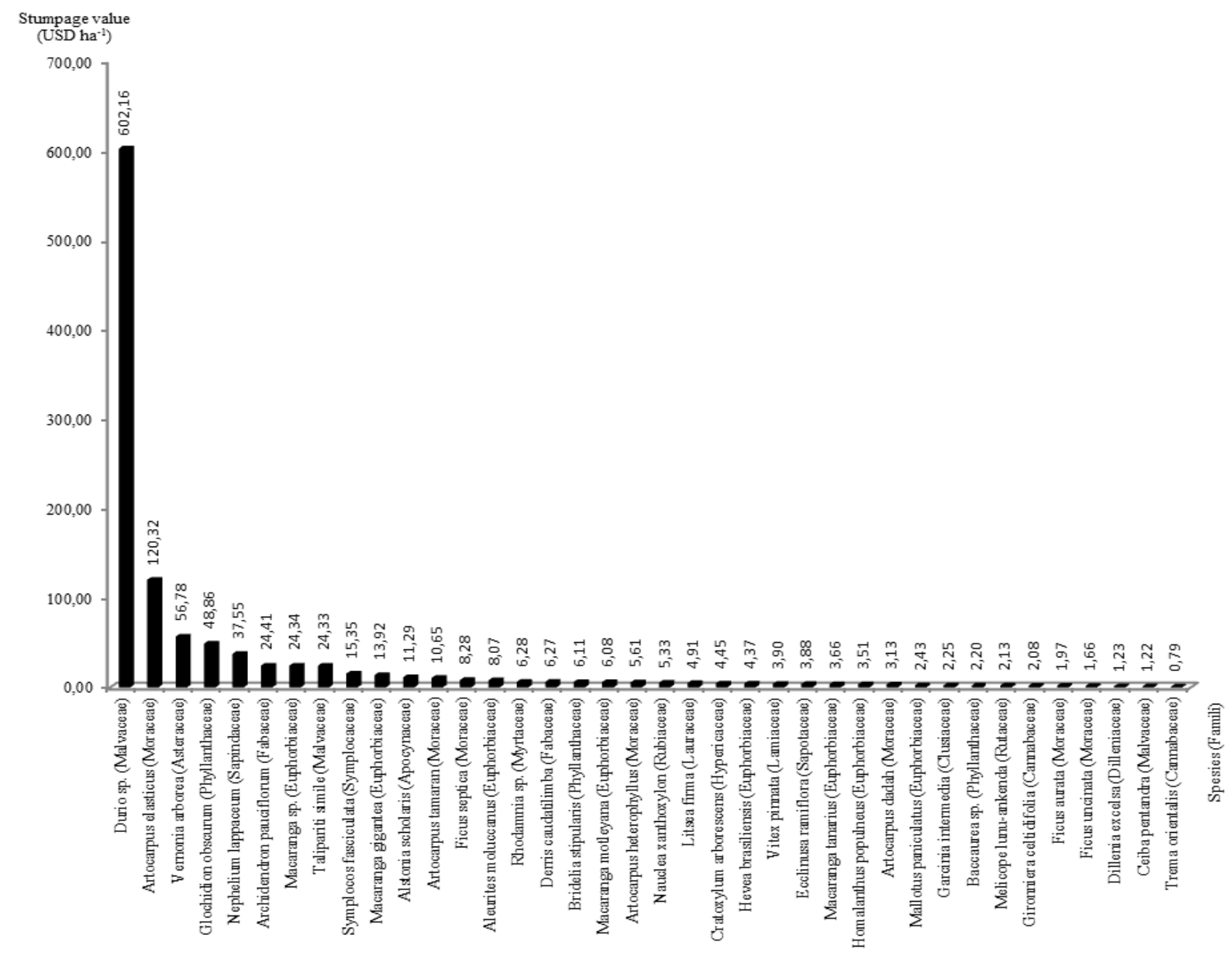

Figure 5. Stumpage value of trees in 0.4 ha of 50 years old secondary forest in East Kalimantan

Karmini, Karyati, Widiati KY. 2020a. The role of tropical abandoned land relative to ecological and economic aspects. For Soc 4 (1): 181-194. DOI: $10.24259 /$ fs.v4i1.8939

Karmini, Karyati, Widiati KY. 2020b. The ecological and economic values of secondary forest on abandoned land in Samarinda, East Kalimantan Province, Indonesia. Biodiversitas 21(11): 5550-5558. DOI: $10.13057 /$ biodiv/d211164

Karyati, Ipor IB, Jusoh I, Wasli ME, Seman IA. 2013. Composition and diversity of plant seedlings and saplings at early secondary succession of fallow lands in Sabal, Sarawak. Acta Biol Malay 2 (3): 85-94. DOI: $10.7593 / \mathrm{abm} / 2.3 .85$

Karyati, Ipor IB, Jusoh I, Wasli ME. 2018. Tree stand floristic dynamics in secondary forests of different ages in Sarawak, Malaysia. Biodiversitas 19 (3): 767-773. DOI: 10.13057/biodiv/d190302

Karyati, Widiati KY, Karmini. 2021. Ecological and Economic Aspects of Abandoned Land in East Kalimantan. Mulawarman University Press, Samarinda. [Indonesian]

Khamyong $\mathrm{N}$, Wangpakapattanawong $\mathrm{P}$, Chairuangsri $\mathrm{S}$, Inta A, Tiansawat P. 2018. Tree species composition and height-diameter allometry of three forest types in Northern Thailand. CMU J Nat Sci 17 (4): 289-306. DOI: 10.12982/CMUJNS.2018.0021

Krebs CJ. 2001. Ecology, 5th Ed. Addison Wesley Longman Inc, USA.

Manyanda BJ, Nzunda EF, Mugasha WA, Malimbwi RE. 2021. Efects of drivers and their variations on the number of stems and aboveground carbon removals in miombo woodlands of mainland Tanzania. Carbon Balance Manag 16 (16): 1-15. DOI: 10.1186/s13021-02100180-9
Matsuo T, Martinez-Ramos M, Bongers F, van der Sande MT, Poorter L. 2021. Forest structure drives changes in light heterogeneity during tropical secondary forest succession. $\mathrm{J}$ Ecol 00: 1-14. DOI: $10.1111 / 1365-2745.13680$

Matthew NK, Shuib A, Ramachandran S, Afandi SHM. 2019. Total economic value of ecosystem services in Malaysia: A review. J Sustain Sci Manag 14 (5): 148-163.

McClellan M, Montgomery R, Nelson K, Becknell J. 2018. Comparing forest structure and biodiversity on private and public land: Secondary tropical dry forests in Costa Rica. Biotropica 50 (3): 510519. DOI: 10.1111/btp.12536

Naime J, Mora F, Sánchez-Martínez M, Arreola F, Balvanera P. 2020. Economic valuation of ecosystem services from secondary tropical forests: Trade-offs and implications for policy making. For Ecol Manag 473: 1-10. DOI: 10.1016/j.foreco.2020.118294

Nath PC, Nath AJ, Reang D, Lal R, Das AK. 2021. Tree diversity, soil organic carbon lability and ecosystem carbon storage under a fallow age chronosequence in North East India. Environ Sustain Indic 10: 19. DOI: 10.1016/j.indic.2021.100122

Nitanan KM, Shuib A, Sridar R, Kunjuraman V, Zaiton S, Herman MAS. 2020. The total economic value of forest ecosystem services in the tropical forests of Malaysia. Int For Rev 22 (4): 485-503. DOI: $10.1505 / 146554820831255551$

Norden N, Chazdon RL, Chao A, Jiang Y, Vílchez-Alvarado B. 2009. Resilience of tropical rain forests: tree community reassembly in secondary forests. Ecol Lett 12 (5): 385-394. DOI: 10.1111/j.14610248.2009.01292.x 
Odum PE. 2005. Fundamentals of Ecology, 5th Ed. Thomson Brooks/Cole, Belmont CA.

Ohtsuka T. 2002. Early stages of secondary succession on abandoned cropland in North-East Borneo Island. Ecol Res 14: 281-290. DOI: 10.1046/j.1440-1703.1999.143304.x

Otuoma J, Ouma G, Okeyo D, Anyango B. 2014. Species composition and stand structure of secondary and plantation forests in a Kenya rainforest. J Hortic For 6 (4): 38-49. DOI: 10.5897/JHF2014.0343
Supriatna J. 2018. Biodiversity Indexes: Value and Evaluation Purposes. The 4th International Workshop on UI GreenMetric World University Rankings (IWGM 2018). E3S Web of Conferences. 48: 01001. DOI: 10.1051/e3sconf/20184801001

Wasli ME, Tanaka S, Kendawang JJ, Abdu A, Lat J, Morooka Y, Long SM, Sakurai K. 2011. Soils and vegetation condition of natural forests and secondary fallow forests within Batang Ai National Park Boundary, Sarawak, Malaysia. Kuroshio Sci 5 (1): 67-76. 